\title{
Theoretical and mathematical models of the torque of mechanical losses in the pump used in a hydrostatic drive
}

\author{
Zygmunt Paszota, Prof. \\ Gdansk University of Technology
}

\begin{abstract}
The paper presents theoretical and mathematical models of the torque of mechanical losses in the pump with theoretical (constant) capacity $q_{P t}$ per one shaft revolution (with constant theoretical working volume $V_{P t}$ ) and geometrical (variable) capacity $q_{P g v}$ per one shaft revolution (with variable volume $V_{P g}$ ). The models may be used in the laboratory and simulation investigations of the pump energy efficiency and the hydrostatic drive efficiency.
\end{abstract}



Key words: hydrostatic drive; displacement pump; energy efficiency

\section{INTRODUCTION}

The paper is a continuation of the work presented in references $[1 \div 18]$, aimed at creating a method of evaluation of the losses and energy efficiency of hydrostatic drives as well as the used displacement machines (pump and hydraulic motors). The method is based on mathematical models of energy losses in the pumps, in hydraulic motors and in other elements of a hydrostatic drive system.

The description of pump losses and energy efficiency is based on the diagram of power increase in the drive system opposite to the direction of power flow, replacing the Sankey diagram of power decrease in the direction of power flow [18]. The Sankey diagram of decrease (division) of power in a drive system in the direction of power flow is the main reason of incorrect evaluation of the energy losses, a. o. in the displacement pumps and hydraulic motors used in hydrostatic drive systems.

During the operation of a hydrostatic drive system, the energy losses force the increase of power in the system - from useful power $\mathrm{P}_{\mathrm{Mu}}$ required by the hydraulic motor driven machine to the power $\mathrm{P}_{\mathrm{Pc}}$ consumed by the pump on the pump shaft.

In the description of power flow in a drive system and the powers of energy losses connected with the flow, the notions: ,power decrease", „power division", „power loss" should not be used.

The notion associated with the power of energy losses in a drive system is ,increase of power".

Figure 1 presents a diagram of power increase in a displacement pump opposite to the direction of power flow, which replaces the Sankey diagram of power decrease in the direction of power flow.
The aim of the paper is to present the theoretical and mathematical models of mechanical losses in the pump „working chambers - shaft" assembly. Pump is a displacement machine with theoretical (constant) capacity $\mathrm{q}_{\mathrm{Pt}}$ per one shaft revolution (with constant theoretical working volume $\mathrm{V}_{\mathrm{Pt}}$ ) or with geometrical (variable) capacity $\mathrm{q}_{\mathrm{Pgv}}$ per one shaft revolution (with variable geometrical working volume $\mathrm{V}_{\text {Pgv }}$ ).

The models may be used in the laboratory and simulation investigations of the pump mechanical losses, allowing to evaluate the pump energy efficiency and the hydrostatic drive efficiency .

\section{THEORETICAL MODELS OF THE TORQUE $M_{P Y}$ OF MECHANICAL LOSSES IN THE PUMP „WORKING CHAMBERS - SHAFT" ASSEMBLY}

The pump shaft torque $\mathbf{M}_{\mathbf{p}}$ (required by the pump of its driving motor) must be greater than the torque $\mathbf{M}_{\mathrm{Pi}}$ indicated in the pump working chambers because of the necessity of balancing also the torque $M_{P m}$ of mechanical losses in the „working chambers - shaft" assembly. The assembly forms the working chambers and changes their capacity and also connects the working chambers with the shaft. Therefore, the torque $\mathrm{M}_{\mathrm{P}}$ required on the pump shaft is a sum of the torque $\mathrm{M}_{\mathrm{Pi}}$ indicated in the working chambers and the torque $\mathrm{M}_{\mathrm{Pm}}$ of mechanical losses in the pump ,working chambers - shaft" assembly:

$$
\mathrm{M}_{\mathrm{P}}=\mathrm{M}_{\mathrm{Pi}}+\mathrm{M}_{\mathrm{Pm}}
$$

Torque $\mathrm{M}_{\mathrm{Pm}}$ of mechanical losses in a pump with variable capacity $\mathrm{q}_{\mathrm{Pgv}}$ per one shaft revolution is, at the maximum value of $q_{P g v}$ i.e. $q_{P g v}=q_{P t}\left(\right.$ with $\left.b_{P}=q_{P g v} / q_{P t}=1\right)$, equal to the torque 

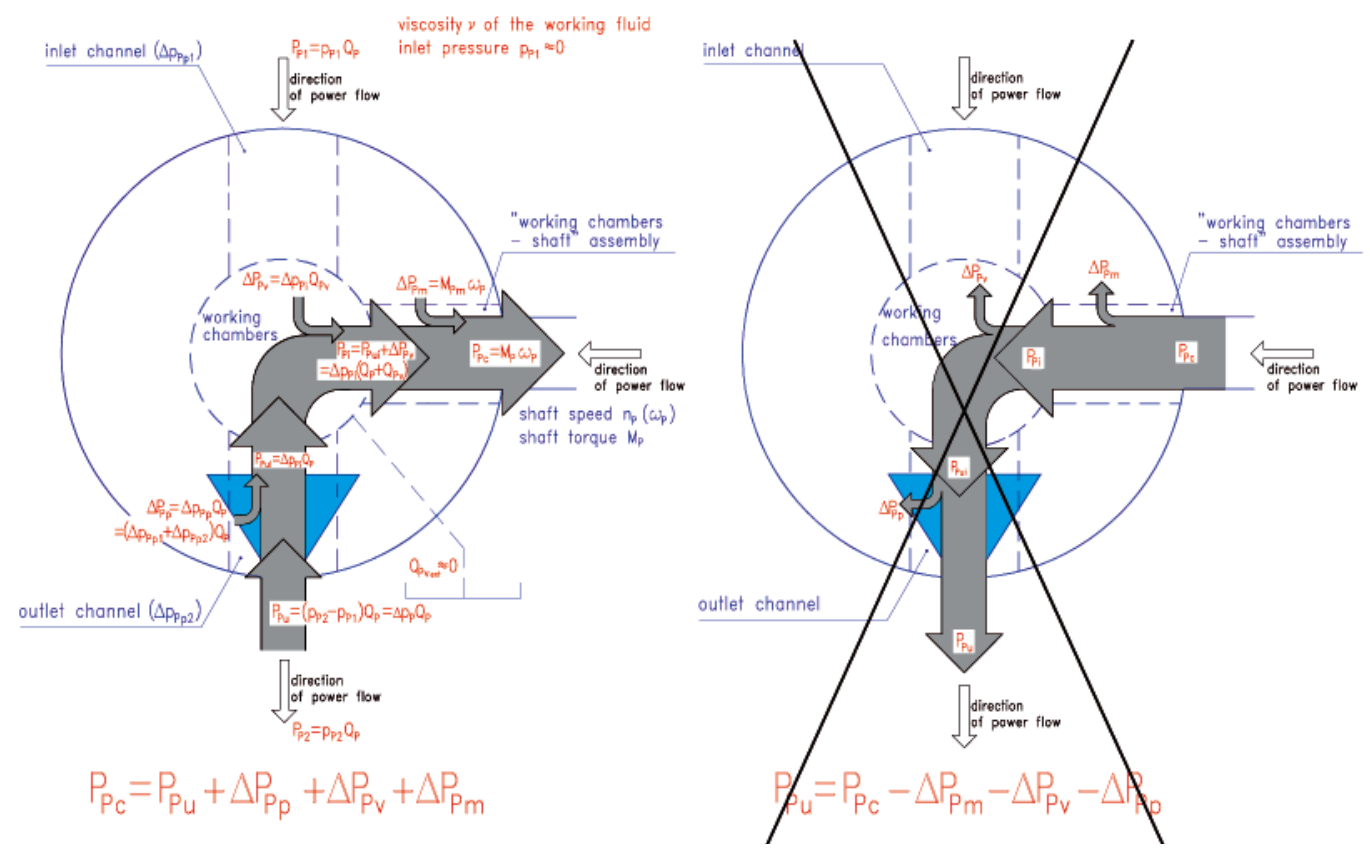

Fig. 1. Diagram of power increase in a displacement pump opposite to the direction of power flow, replacing the Sankey diagram of power decrease in the direction of power flow

of mechanical losses in that pump working as a pump with constant capacity $\mathrm{q}_{\mathrm{Pt}}$ per one shaft revolution. The theoretical and mathematical models describing the torque $\mathrm{M}_{\mathrm{Pm}}$ of mechanical losses in a pump with variable capacity $\mathrm{q}_{\mathrm{Pgv}}$ per one shaft revolution may be based on models of $\mathrm{M}_{\mathrm{Pm}}$ describing the torque of mechanical losses in a pump with constant capacity $\mathrm{q}_{\mathrm{Pt}}$ per one shaft revolution (with $b_{p}=1$ ). Considering the models describing the torque of pump mechanical losses, we assume, that the pump is driven with practically constant rotation speed $\mathrm{n}_{\mathrm{p}}$, and the decrease of shaft speed (decrease of the pump driving motor speed as a result of the increase of torque $\mathrm{M}_{\mathrm{P}}$ loading the motor shaft) to a value $\mathrm{n}_{\mathrm{P}}<\mathrm{n}_{\mathrm{P} 0}\left(\mathrm{n}_{\mathrm{P} 0}\right.$ - rotational speed of unload pump driving motor) is negligible from the point of view of the impact of speed $n_{P}$ on the value of torque $M_{P m}$ of mechanical losses.

Torque $M_{\mathrm{Pm}}$ of mechanical losses in the pump is mainly an effect of friction forces between elements of the „working chambers - shaft" assembly, depending, among other, on the torque $M_{P i}$ indicated in the working chambers $-M_{P_{i}}=$ $=\mathbf{q}_{\mathrm{Pgv}} \Delta \mathbf{p}_{\mathrm{Pi}} / \mathbf{2} \Pi=\mathbf{b}_{\mathrm{P}} \mathbf{q}_{\mathrm{Pt}} \Delta \mathbf{p}_{\mathrm{Pi}} / 2 \Pi$.

Friction forces between elements of the ,working chambers - shaft" assembly are, to some extent, also an effect of the load on those elements of the inertia forces from rotational and reciprocating motion and depend on the pump capacity $q_{\text {Pgv }}$ per one shaft revolution (b $b_{P}$ coefficient).

In the piston (axial or radial) pumps with casing (crankcase) filled with liquid, friction forces also occur between elements of the "working chambers - shaft" assembly and the liquid and depend on the liquid viscosity $v$.

The value of torque $\mathrm{M}_{\mathrm{Pm} \mid \Delta \mathrm{p}_{\mathrm{pi}}, \mathrm{b}_{\mathrm{p}}, v_{\mathrm{n}}}$ of mechanical losses in the pump „,working chambers - shaft” assembly, loaded with indicated increase $\Delta \mathrm{p}_{\mathrm{Pi}}$ of pressure in the working chambers, in the pump operating at the capacity $\mathrm{q}_{\mathrm{Pgv}}=\mathrm{b}_{\mathrm{p}} \mathrm{q}_{\mathrm{Pt}}$ per one shaft revolution and discharging the working liquid with (constant) reference viscosity $v_{n}$, can be described as a sum of torque $\mathrm{M}_{\mathrm{Pm} \mid \Delta \mathrm{p}_{\mathrm{p} i}, \mathrm{~b}_{\mathrm{p}}, v_{\mathrm{n}}}$ of mechanical losses in the unloaded pump (torque of the losses when the indicated increase $\Delta \mathrm{p}_{\mathrm{pi}}$ of pressure in the pump working chambers is equal to zero $-\Delta \mathrm{p}_{\mathrm{Pi}}=0$ ) and increase $\mathrm{M}_{\mathrm{Pm} / \Delta \mathrm{p} p \mathrm{i}, \mathrm{b}_{\mathrm{p}, v_{\mathrm{n}}}}$ of torque of mechanical losses, the increase being an effect of loading the assembly structure elements with torque $\mathrm{M}_{\mathrm{Pi}}$ indicated in the pump working chambers (torque $\mathrm{M}_{\mathrm{Pi}}$ appearing when the indicated increase $\Delta \mathrm{p}_{\mathrm{Pi}}$ of pressure in the pump working chambers is greater than zero $\left.-\Delta \mathrm{p}_{\mathrm{Pi}}>0\right)$ :

$\mathrm{M}_{\mathrm{Pm} \mid \Delta \mathrm{p}_{\mathrm{Pi}}, \mathrm{b}_{\mathrm{P}}, v_{\mathrm{n}}}=\mathrm{M}_{\mathrm{Pm} \mid \Delta \mathrm{p}_{\mathrm{Pi}}=0, \mathrm{~b}_{\mathrm{P}}, v_{\mathrm{n}}}+\Delta \mathrm{M}_{\mathrm{Pm} \mid \Delta \mathrm{p}_{\mathrm{Pi}}, \mathrm{b}_{\mathrm{P}}, v_{\mathrm{n}}}$

Torque $\mathrm{M}_{\mathrm{Pi}}$ indicated in the pump working chambers is proportional to the increase $\Delta \mathrm{p}_{\mathrm{Pi}}$ of pressure in the chambers and to the active volume of the chambers created during one pump shaft revolution, which is equal to the theoretical capacity $\mathrm{q}_{\mathrm{Pt}}$ per one shaft revolution in a pump with constant capacity per one shaft revolution or to the geometrical capacity $\mathrm{q}_{\mathrm{Pgv}}=\mathrm{b}_{\mathrm{P}} \mathrm{q}_{\mathrm{Pt}}$ per one shaft revolution in a pump with variable capacity per one shaft revolution.

Therefore, the „working chambers - shaft” assembly structure elements are loaded:

- in a pump with theoretical (constant) capacity $\mathrm{q}_{\mathrm{Pt}}$ per one shaft revolution - with indicated torque:

$$
\mathrm{M}_{\mathrm{Pi}}=\frac{\mathrm{q}_{\mathrm{Pt}} \Delta \mathrm{p}_{\mathrm{Pi}}}{2 \Pi}
$$

- in a pump with geometrical (variable) capacity $q_{P g v}$ per one shaft revolution - with indicated torque:

$$
\mathrm{M}_{\mathrm{Pi}}=\frac{\mathrm{q}_{\mathrm{Pgv}} \Delta \mathrm{p}_{\mathrm{Pi}}}{2 \Pi}=\frac{\mathrm{b}_{\mathrm{P}} \mathrm{q}_{\mathrm{Pt}} \Delta \mathrm{p}_{\mathrm{Pi}}}{2 \Pi}
$$

which, in effect, causes a differentiated intensity of the increase $\mathrm{M}_{\mathrm{Pm} \mid \Delta \mathrm{p}_{\mathrm{p}}, \mathrm{b}_{\mathrm{p}}, v_{\mathrm{n}}}$ of the torque of mechanical losses, determined, with different values of coefficient $b_{P}=q_{P g v} / q_{P t}$, as a function of the increase $\Delta \mathrm{p}_{\mathrm{Pi}}$ of pressure in the pump working chambers.

In the theoretical and mathematical models describing the torque $\mathrm{M}_{\mathrm{Pm} \mid \Delta \mathrm{p}_{\mathrm{pi}}, \mathrm{b}_{\mathrm{p}}, v_{\mathrm{n}}}$ of mechanical losses a hypothesis is assumed, that the increase $\mathbf{M}_{\mathbf{P m} \mid \Delta p_{p}, b_{p}, v_{n}}$ of the torque of mechanical losses in the pump is proportional to the torque $\mathbf{M}_{\mathrm{Pi}}$ indicated in its working chambers (Fig. 2 and 5).

The impact of inertia forces of the, working chambers - shaft" assembly elements, performing the rotational and reciprocating motion in the pump, on the torque $M_{P m}$ of mechanical losses can be presented, under the assumption that rotational speed $n_{P}$ of the pump driving motor changes only in a small range, as a function of capacity $q_{P g v}$ 


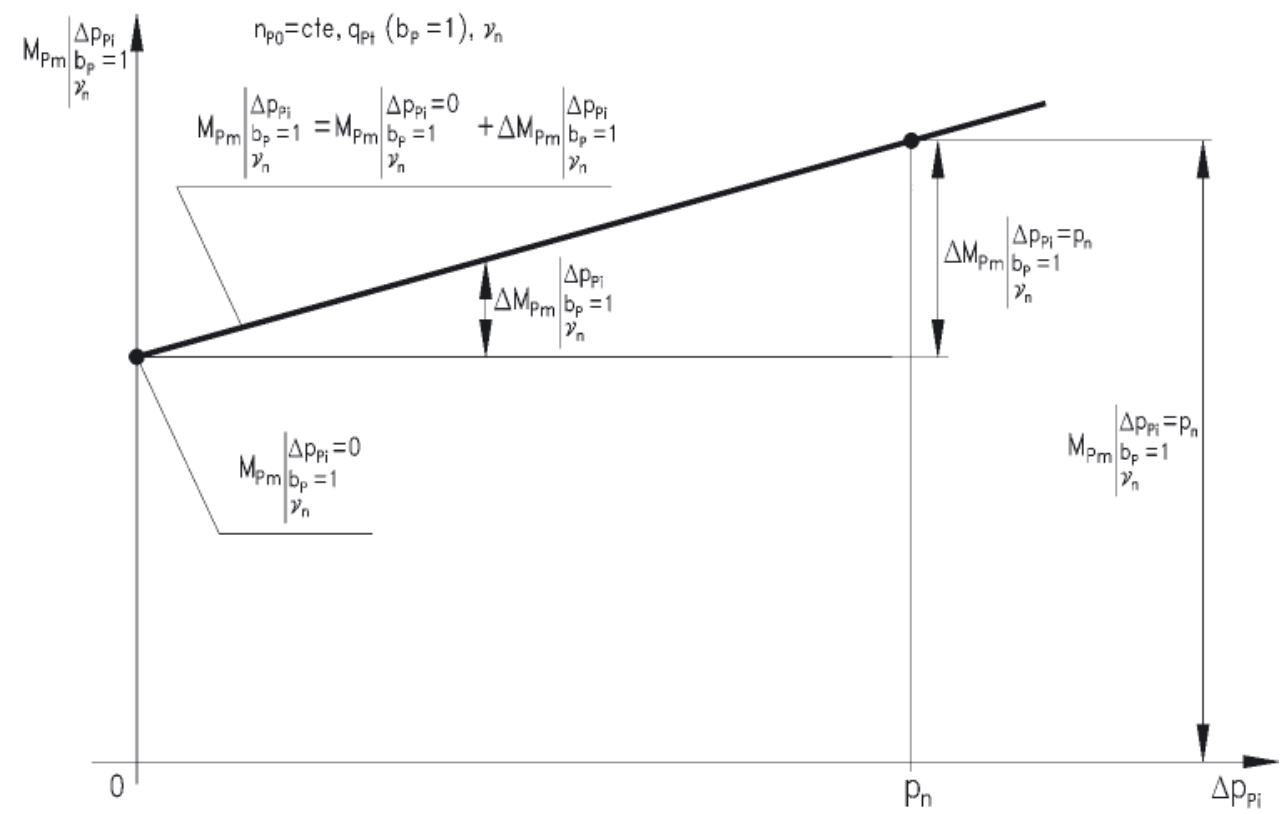

Fig. 2. Torque $M_{P m \mid \Delta p_{p i}, b_{p}=1, v_{n}}$ of mechanical losses in the pump with constant capacity $q_{P t}$ per one shaft revolution $\left(b_{P}=1\right)$, with working liquid reference viscosity $v_{n}$, as a function of the indicated increase $\Delta p_{P i}$ of pressure in the pump working chambers - graphical interpretation of theoretical model (2)

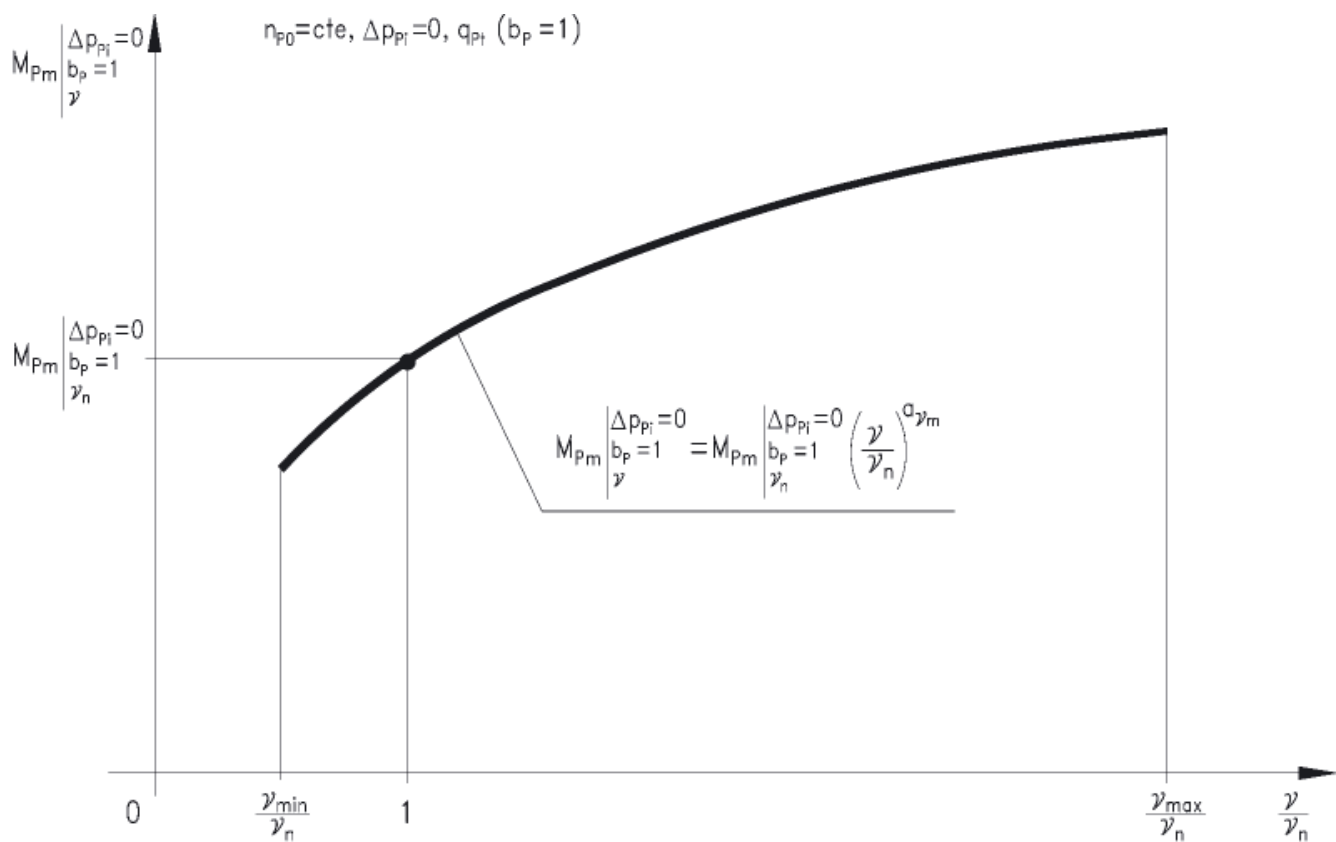

Fig. 3. Torque $M_{P m \mid \Delta p_{p i}=0, b_{p}=1, v}$ of mechanical losses in a piston (axial or radial) pump with crankcase filled with liquid and with constant capacity $q_{P t}$ per one shaft revolution $\left(b_{P}=1\right)$, at the indicated increase $\Delta p_{P i}=0$ of pressure in the pump working chambers, as a function of the ratio of viscosity $v$ to reference viscosity $v_{n}-v / v_{n}$ - graphical interpretation of theoretical model (3); torque $M_{P m \mid \Delta p_{p i}=0, b_{p}=1, v}$ of mechanical losses in the pump without the crankcase filled with liquid is practically independent of the liquid viscosity $v$ and is determined at the liquid reference viscosity $v_{n}$

( $b_{P}$ coefficient) per one shaft revolution of a variable capacity pump. Inertia forces do not depend on the value of increase $\Delta \mathbf{p}_{\mathrm{Pi}}$ of pressure in the working chambers, therefore their impact on the torque $M_{\mathrm{Pm}}$ of mechanical losses in the pump may be included in the evaluation of the torque $M_{\mathrm{Pm}_{\mid} \mid \Delta \mathrm{p}_{\mathrm{pi}}=0, \mathrm{~b}_{\mathrm{p}}, v_{\mathrm{n}}}$ of mechanical losses determined at the increase $\Delta \mathbf{p}_{\mathrm{Pi}}=\mathbf{0}$ (Fig. 5).

The impact of the friction forces between the ,working chambers - shaft" assembly elements and the liquid in the casing (crankcase) of the piston pump on the torque $\mathbf{M}_{\mathrm{Pm}}$ of mechanical losses in the pump can be presented, under the assumption that speed $n_{\mathrm{P}}$ changes in a small range, as a relation of $M_{P m}$ to the viscosity $v$ and to the capacity $q_{P g v}$ ( $b_{P}$ coefficient) per one shaft revolution (Fig. 3, 4, 6, 7).
It is assumed, that the impact of liquid viscosity $v$ on the friction forces between the ,working chambers - shaft" elements and the liquid in the piston pump casing (crankcase), and in effect on the torque $M_{\mathrm{Pm}}$ of mechanical losses in the pump, can be evaluated at one level of the increase $\Delta \mathrm{p}_{\mathrm{Pi}}$ of pressure indicated in the working chambers, e.g. at the increase $\Delta \mathbf{p}_{\mathrm{Pi}}=\mathbf{0}$ (Fig. 3, 6). This assumption is connected with a simplification assuming that there is no significant impact of the increase $\Delta \mathrm{p}_{\mathrm{Pi}}$ of pressure on the liquid viscosity $v$ and with assuming in the model describing the torque $\mathrm{M}_{\mathrm{Pm}}$ of mechanical losses the liquid viscosity $v$ determined in the pump inlet conduit [at pressure $\mathrm{p}_{\mathrm{P} 1}$ equal to zero (at liquid absolute pressure equal to atmospheric pressure)]. 
The impact of inertia forces of structure elements performing the rotational or reciprocating motion in the pump and also the impact of liquid viscosity $v$ on the torque $\mathrm{M}_{\mathrm{Pm}}$ of mechanical losses in the pump is then described in the model of the torque $\mathrm{M}_{\mathrm{Pm} \mid \Delta \mathrm{ppi}=0, \mathrm{~b}_{\mathrm{p}, v}}$ of those losses in an unloaded pump (at $\Delta \mathrm{p}_{\mathrm{Pi}}=0$ ) supplied with working liquid of changing viscosity $v$.

The proposed theoretical models describing the torque $M_{P m \mid \Delta p_{p i}=0, b_{p}, v}$ of mechanical losses in an unloaded pump (at the indicated increase $\Delta \mathbf{p}_{\mathrm{Pi}}=\mathbf{0}$ of pressure in the working chambers) and at changing working liquid viscosity $v$ [the impact of liquid viscosity $v$ occurs in the piston pumps with liquid filling the casing (crankcase)] have the form:

- in the pump with theoretical (constant) capacity $\mathrm{q}_{\mathrm{Pt}}\left(\mathrm{b}_{\mathrm{P}}=1\right)$ per one shaft revolution (Fig. 3):

$$
\mathrm{M}_{\mathrm{Pm} \mid \Delta \mathrm{p}_{\mathrm{Pi}}=0, \mathrm{~b}_{\mathrm{P}}=1, v}=\mathrm{M}_{\mathrm{Pm} \mid \Delta \mathrm{p}_{\mathrm{Pi}}=0, \mathrm{~b}_{\mathrm{P}}=1, v_{\mathrm{n}}}\left(\frac{v}{v_{\mathrm{n}}}\right)^{\mathrm{a}_{v \mathrm{~m}}}
$$

- in the pump with geometrical (variable) capacity $\mathrm{q}_{\mathrm{Pgv}}$ $\left(q_{P g v}=b_{P} q_{P t}\right)$ per one shaft revolution (Fig. 6):

$$
\begin{gathered}
\mathrm{M}_{\mathrm{Pm} \mid \Delta \mathrm{p}_{\mathrm{Pi}}=0, \mathrm{~b}_{\mathrm{P}}, v}= \\
=\left(\mathrm{M}_{\mathrm{Pm} \mid \Delta \mathrm{p}_{\mathrm{Pi}}=0, \mathrm{~b}_{\mathrm{P}}=0, v_{\mathrm{n}}}+\Delta \mathrm{M}_{\mathrm{Pm} \mid \Delta \mathrm{p}_{\mathrm{Pi}}=0, \mathrm{~b}_{\mathrm{P}}, v_{\mathrm{n}}}\right)\left(\frac{v}{v_{\mathrm{n}}}\right)^{\mathrm{a}_{v \mathrm{~m}}}
\end{gathered}
$$

where:

$$
\begin{gathered}
\Delta \mathrm{M}_{\mathrm{Pm} \mid \Delta \mathrm{p}_{\mathrm{Pi}}=0, \mathrm{~b}_{\mathrm{P}}, v_{\mathrm{n}}}= \\
=\mathrm{M}_{\mathrm{Pm} \mid \Delta \mathrm{p}_{\mathrm{Pi}}=0, \mathrm{~b}_{\mathrm{P}}, v_{\mathrm{n}}}-\mathrm{M}_{\mathrm{Pm} \mid \Delta \mathrm{p}_{\mathrm{Pi}}=0, \mathrm{~b}_{\mathrm{P}}=0, v_{\mathrm{n}}}= \\
=\left(\mathrm{M}_{\mathrm{Pm} \mid \Delta \mathrm{p}_{\mathrm{Pi}}=0, \mathrm{~b}_{\mathrm{P}}=1, v_{\mathrm{n}}}-\mathrm{M}_{\mathrm{Pm} \mid \Delta \mathrm{p}_{\mathrm{Pi}}=0, \mathrm{~b}_{\mathrm{P}}=0, v_{\mathrm{n}}}\right) \mathrm{b}_{\mathrm{P}}
\end{gathered}
$$

Exponent $\mathbf{a}_{v \mathrm{~m}}$ in expressions (3) and (4) describes the impact of the ratio $v / v_{n}$ of working liquid $v$ to reference viscosity $v_{n}=35 \mathrm{~mm}^{2} \mathrm{~s}^{-1}$ on the value of torque of mechanical losses in a piston displacement machine with liquid filling the casing (crankcase) (in the pump and in the hydraulic motor).

The increase $M_{P m \mid \Delta p_{p i}, b_{p}, v}$ of the torque of mechanical losses in the pump, due to the load of the assembly elements with the indicated torque $M_{\mathrm{Pi}}$ resulting from the indicated increase $\Delta \mathbf{p}_{\mathrm{Pi}}$ of pressure in the pump working chambers, is independent of the inertia forces of elements performing the rotational or reciprocating motion in the pump. It is also practically independent of the working liquid viscosity $v$; therefore, it may be determined at one viscosity value, e.g. at the liquid reference viscosity $\mathbf{v}_{\mathbf{n}}$ (Fig. 4,7 ).

The proposed theoretical models describing the increase $M_{P m \mid \Delta p_{p i}, b_{p}, v}$ of the torque of mechanical losses in the pump, resulting from the indicated increase $\Delta \mathrm{p}_{\mathrm{Pi}}$ of pressure in the working chambers, have the form:

- in the pump with theoretical (constant) capacity $\mathrm{q}_{\mathrm{Pt}}\left(\mathrm{b}_{\mathrm{P}}=1\right)$ per one shaft revolution (Fig. 4):

$$
\begin{aligned}
& \Delta \mathrm{M}_{\mathrm{Pm} \mid \Delta \mathrm{p}_{\mathrm{Pi}}, \mathrm{b}_{\mathrm{P}}=1, v}=\Delta \mathrm{M}_{\mathrm{Pm} \mid \Delta \mathrm{p}_{\mathrm{Pi}}, \mathrm{b}_{\mathrm{P}}=1, v_{\mathrm{n}}}= \\
= & \mathrm{M}_{\mathrm{Pm} \mid \Delta \mathrm{p}_{\mathrm{Pi}}, \mathrm{b}_{\mathrm{P}}=1, v_{\mathrm{n}}}-\mathrm{M}_{\mathrm{Pm} \mid \Delta \mathrm{p}_{\mathrm{Pi}}=0, \mathrm{~b}_{\mathrm{P}}=1, v_{\mathrm{n}}}=
\end{aligned}
$$

$$
=\left(M_{P m \mid \Delta p_{P i}=p_{n}, b_{P}=1, v_{n}}-M_{P m \mid \Delta p_{P i}=0, b_{P}=1, v_{n}}\right) \frac{\Delta p_{P i}}{p_{n}}
$$

- in the pump with geometrical (variable) capacity $\mathrm{q}_{\mathrm{Pgv}}$ $\left(\mathrm{q}_{\mathrm{Pgv}}=\mathrm{b}_{\mathrm{P}} \mathrm{q}_{\mathrm{Pt}}\right)$ per one shaft revolution (Fig. 7):

$$
\begin{gathered}
\Delta \mathrm{M}_{\mathrm{Pm} \mid \Delta \mathrm{p}_{\mathrm{Pi}}, \mathrm{b}_{\mathrm{P}}, v}=\Delta \mathrm{M}_{\mathrm{Pm} \mid \Delta \mathrm{p}_{\mathrm{Pi}}, \mathrm{b}_{\mathrm{P}}, v_{\mathrm{n}}}= \\
=\mathrm{M}_{\mathrm{Pm} \mid \Delta \mathrm{p}_{\mathrm{Pi}}, \mathrm{b}_{\mathrm{P}}, v_{\mathrm{n}}}-\mathrm{M}_{\mathrm{Pm} \mid \Delta \mathrm{p}_{\mathrm{Pi}}=0, \mathrm{~b}_{\mathrm{P}}, v_{\mathrm{n}}}= \\
=\left(\mathrm{M}_{\mathrm{Pm} \mid \Delta \mathrm{p}_{\mathrm{Pi}}=\mathrm{p}_{\mathrm{n}}, \mathrm{b}_{\mathrm{P}}=1, v_{\mathrm{n}}}+\right.
\end{gathered}
$$

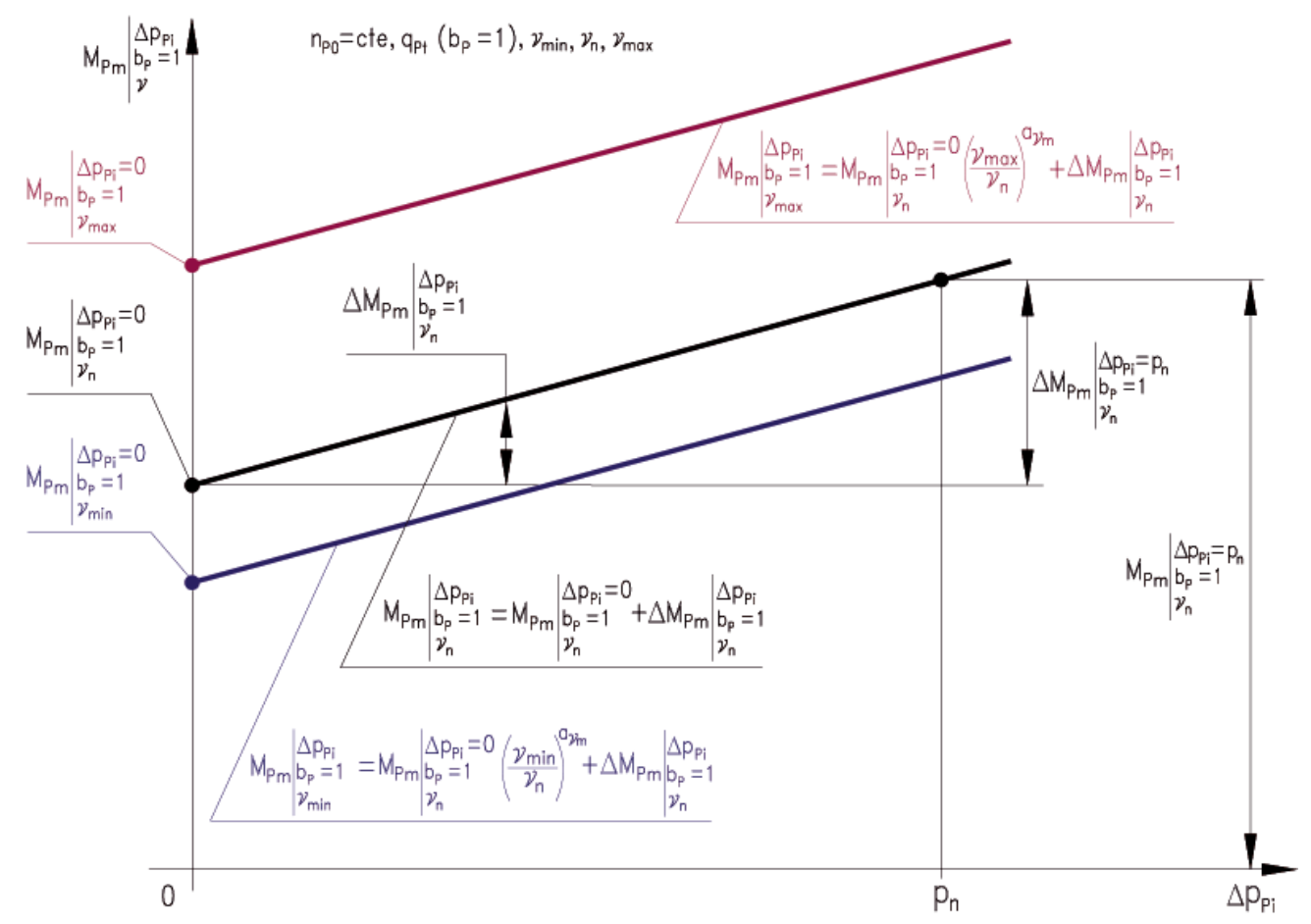

Fig. 4. Torque $M_{P m \mid \Delta p_{p i}, b_{p}=1, v}$ of mechanical losses in a piston (axial or radial) pump with crankcase filled with liquid and with constant capacity $q_{P t}$ per one shaft revolution $\left(b_{P}=1\right)$, as a function of the indicated increase $\Delta p_{P i}$ of pressure in the pump working chambers - graphical interpretation of theoretical models (2) and (8); liquid viscosity $v_{\text {min }}, v_{n}$ and $v_{\max }$. Torque $M_{P m \mid \Delta p}$ i. $b_{p}=1, v$ of mechanical losses in the pump without the crankcase filled with liquid is practically independent of the liquid viscosity $v$ and is determined at the liquid reference viscosity $v_{n}$ 
In effect, the proposed theoretical models describing the torque $M_{\mathrm{Pm}}$ of mechanical losses in the pump take the forms:

- in the pump with theoretical (constant) capacity $\mathrm{q}_{\mathrm{Pt}}\left(\mathrm{b}_{\mathrm{P}}=1\right)$ per one shaft revolution (Fig. 4):

$$
\begin{aligned}
& \mathrm{M}_{\mathrm{Pm} \mid \Delta \mathrm{p}_{\mathrm{Pi}}, \mathrm{b}_{\mathrm{P}}=1, v}=\mathrm{M}_{\mathrm{Pm} \mid \Delta \mathrm{p}_{\mathrm{Pi}}=0, \mathrm{~b}_{\mathrm{P}}=1, v_{\mathrm{n}}}\left(\frac{v}{v_{\mathrm{n}}}\right)^{\mathrm{a}_{v \mathrm{~m}}}+ \\
& +\Delta \mathrm{M}_{\mathrm{Pm} \mid \Delta \mathrm{p}_{\mathrm{Pi}}, \mathrm{b}_{\mathrm{P}}=1, v_{\mathrm{n}}}=\mathrm{M}_{\mathrm{Pm} \mid \Delta \mathrm{p}_{\mathrm{Pi}}=0, \mathrm{~b}_{\mathrm{P}}=1, v_{\mathrm{n}}}\left(\frac{v}{v_{\mathrm{n}}}\right)^{\mathrm{a}_{v \mathrm{~m}}}+ \\
& +\left(\mathrm{M}_{\mathrm{Pm} \mid \Delta \mathrm{p}_{\mathrm{Pi}}=\mathrm{p}_{\mathrm{n}}, \mathrm{b}_{\mathrm{P}}=1, v_{\mathrm{n}}}-\mathrm{M}_{\mathrm{Pm} \mid \Delta \mathrm{p}_{\mathrm{Pi}}=0, \mathrm{~b}_{\mathrm{P}}=1, v_{\mathrm{n}}}\right) \frac{\Delta \mathrm{p}_{\mathrm{Pi}}}{\mathrm{p}_{\mathrm{n}}}
\end{aligned}
$$

- in the pump with geometrical (variable) capacity $\mathrm{q}_{\mathrm{Pg}}$ $\left(\mathrm{q}_{\mathrm{Pgv}}=\mathrm{b}_{\mathrm{P}} \mathrm{q}_{\mathrm{Pt}}\right)$ per one shaft revolution (Fig.7):

$$
\mathrm{M}_{\mathrm{Pm} \mid \Delta \mathrm{p}_{\mathrm{Pi}}, \mathrm{b}_{\mathrm{P}}, v}=
$$

$$
\begin{aligned}
=\left(\mathrm{M}_{\mathrm{Pm} \mid \Delta \mathrm{p}_{\mathrm{Pi}}=0, \mathrm{~b}_{\mathrm{P}}=0, v_{\mathrm{n}}}+\Delta \mathrm{M}_{\mathrm{Pm} \mid \Delta \mathrm{p}_{\mathrm{Pi}}=0, \mathrm{~b}_{\mathrm{P}}, v_{\mathrm{n}}}\right)\left(\frac{v}{v_{\mathrm{n}}}\right)^{\mathrm{a}_{v \mathrm{~m}}}+ \\
+\Delta \mathrm{M}_{\mathrm{Pm} \mid \Delta \mathrm{p}_{\mathrm{Pi}}, \mathrm{b}_{\mathrm{P}}, v_{\mathrm{n}}}
\end{aligned}
$$

where:

$$
\begin{gathered}
\Delta \mathrm{M}_{\mathrm{Pm} \mid \Delta \mathrm{p}_{\mathrm{Pi}}=0, \mathrm{~b}_{\mathrm{P}, v_{\mathrm{n}}}}= \\
=\left(\mathrm{M}_{\mathrm{Pm} \mid \Delta \mathrm{p}_{\mathrm{Pi}}=0, \mathrm{~b}_{\mathrm{P}}=1, v_{\mathrm{n}}}-\mathrm{M}_{\mathrm{Pm} \mid \Delta \mathrm{p}_{\mathrm{Pi}}=0, \mathrm{~b}_{\mathrm{P}}=0, v_{\mathrm{n}}}\right) \mathrm{b}_{\mathrm{P}}
\end{gathered}
$$

$$
\Delta \mathrm{M}_{\mathrm{Pm} \mid \Delta \mathrm{p}_{\mathrm{Pi}}, \mathrm{b}_{\mathrm{P}}, v_{\mathrm{n}}}=
$$$$
\left(\mathrm{M}_{\mathrm{Pm} \mid \Delta \mathrm{p}_{\mathrm{Pi}}=\mathrm{p}_{\mathrm{n}}, \mathrm{b}_{\mathrm{P}}=1, v_{\mathrm{n}}}-\mathrm{M}_{\mathrm{Pm} \mid \Delta \mathrm{p}_{\mathrm{Pi}}=0, \mathrm{~b}_{\mathrm{P}}=1, v_{\mathrm{n}}}\right) \mathrm{b}_{\mathrm{P}} \frac{\Delta \mathrm{p}_{\mathrm{Pi}}}{\mathrm{p}_{\mathrm{n}}}
$$

\section{MATHEMATICAL MODELS OF THE TORQUE OF MECHANICAL LOSSES}

In the mathematical models describing the torque $M_{P m}$ of mechanical losses in the pump, coefficients $k_{i}$ of losses are used relating (comparing) the components describing the torque $\mathrm{M}_{\mathrm{Pm}}$ of losses in theoretical models to the pump theoretical torque $\mathbf{M}_{\mathrm{pt}}$. The pump theoretical torque $\mathrm{M}_{\mathrm{Pt}}$ is also a reference value used in the description of the torque $\mathrm{M}_{\mathrm{Pi}}$ indicated in the pump working chambers:

- theoretical torque:

$$
\mathrm{M}_{\mathrm{Pt}}=\frac{\mathrm{q}_{\mathrm{Pt}} \mathrm{p}_{\mathrm{n}}}{2 \Pi}
$$

of the pump, with theoretical (constant) capacity $\mathrm{q}_{\mathrm{Pt}}$ per one shaft revolution $\left(b_{P}=1\right)$, is determined with the increase $\Delta \mathrm{p}_{\mathrm{P}}$ of pressure in the pump equal to the system nominal pressure $p_{n}-\Delta p_{P}=p_{n}$, and with the assumption that there are no pressure and mechanical losses in the pump,

- indicated torque:

$$
\mathrm{M}_{\mathrm{Pi}}=\frac{\mathrm{q}_{\mathrm{Pt}} \Delta \mathrm{p}_{\mathrm{Pi}}}{2 \Pi}=\frac{\mathrm{q}_{\mathrm{Pt}} \mathrm{p}_{\mathrm{n}}}{2 \Pi} \frac{\Delta \mathrm{p}_{\mathrm{Pi}}}{\mathrm{p}_{\mathrm{n}}}=\mathrm{M}_{\mathrm{Pt}} \frac{\Delta \mathrm{p}_{\mathrm{Pi}}}{\mathrm{p}_{\mathrm{n}}}
$$

in working chambers of the pump with theoretical (constant) capacity $\mathrm{q}_{\mathrm{Pt}}$ per one shaft revolution $\left(\mathrm{b}_{\mathrm{P}}=1\right)$ is determined with the indicated increase $\Delta \mathrm{p}_{\mathrm{Pi}}$ of pressure in the working chambers,

- indicated torque:

$$
\begin{aligned}
& \mathrm{M}_{\mathrm{Pi}}=\frac{\mathrm{q}_{\mathrm{Pgv}} \Delta \mathrm{p}_{\mathrm{Pi}}}{2 \Pi}=\frac{\mathrm{b}_{\mathrm{P}} \mathrm{q}_{\mathrm{Pt}} \Delta \mathrm{p}_{\mathrm{Pi}}}{2 \Pi}= \\
& =\frac{\mathrm{q}_{\mathrm{Pt}} \mathrm{p}_{\mathrm{n}}}{2 \Pi} \mathrm{b}_{\mathrm{P}} \frac{\Delta \mathrm{p}_{\mathrm{Pi}}}{\mathrm{p}_{\mathrm{n}}}=\mathrm{M}_{\mathrm{Pt}} \mathrm{b}_{\mathrm{P}} \frac{\Delta \mathrm{p}_{\mathrm{Pi}}}{\mathrm{p}_{\mathrm{n}}}
\end{aligned}
$$

in working chambers of the pump with geometrical (variable) capacity $\mathrm{q}_{\mathrm{Pgv}}=\mathrm{b}_{\mathrm{P}} \mathrm{q}_{\mathrm{Pt}}$ per one shaft revolution is determined with the indicated increase $\Delta \mathrm{p}_{\mathrm{Pi}}$ of pressure in the working chambers.

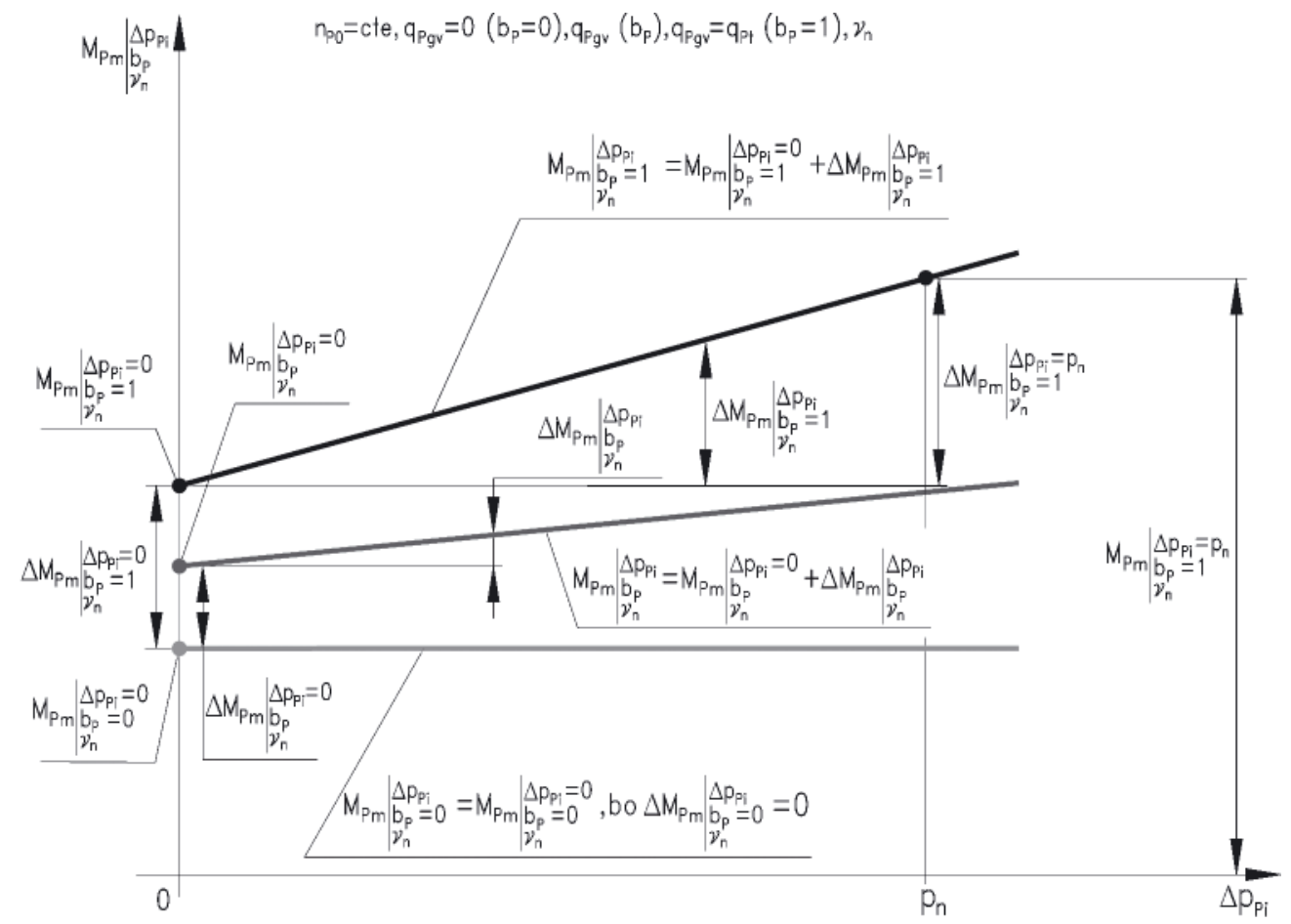

Fig. 5. Torque $M_{P m \mid \Delta p_{p i}, b_{p}, v}$ of mechanical losses in the pump with variable capacity $q_{P g v}=b_{p} q_{P t}$ per one shaft revolution, with working liquid reference viscosity $v_{n}$, as a function of the indicated increase $\Delta p_{P i}$ of pressure in the pump working chambers - graphical interpretation of theoretical models (2) and (7); capacity $q_{P g v}$ per one shaft revolution (coefficient $b_{P}$ of pump capacity): $q_{P g v}=0\left(b_{P}=0\right), q_{P g v}\left(b_{P}\right), q_{P g v}=q_{P t}\left(b_{P}=1\right)$ 


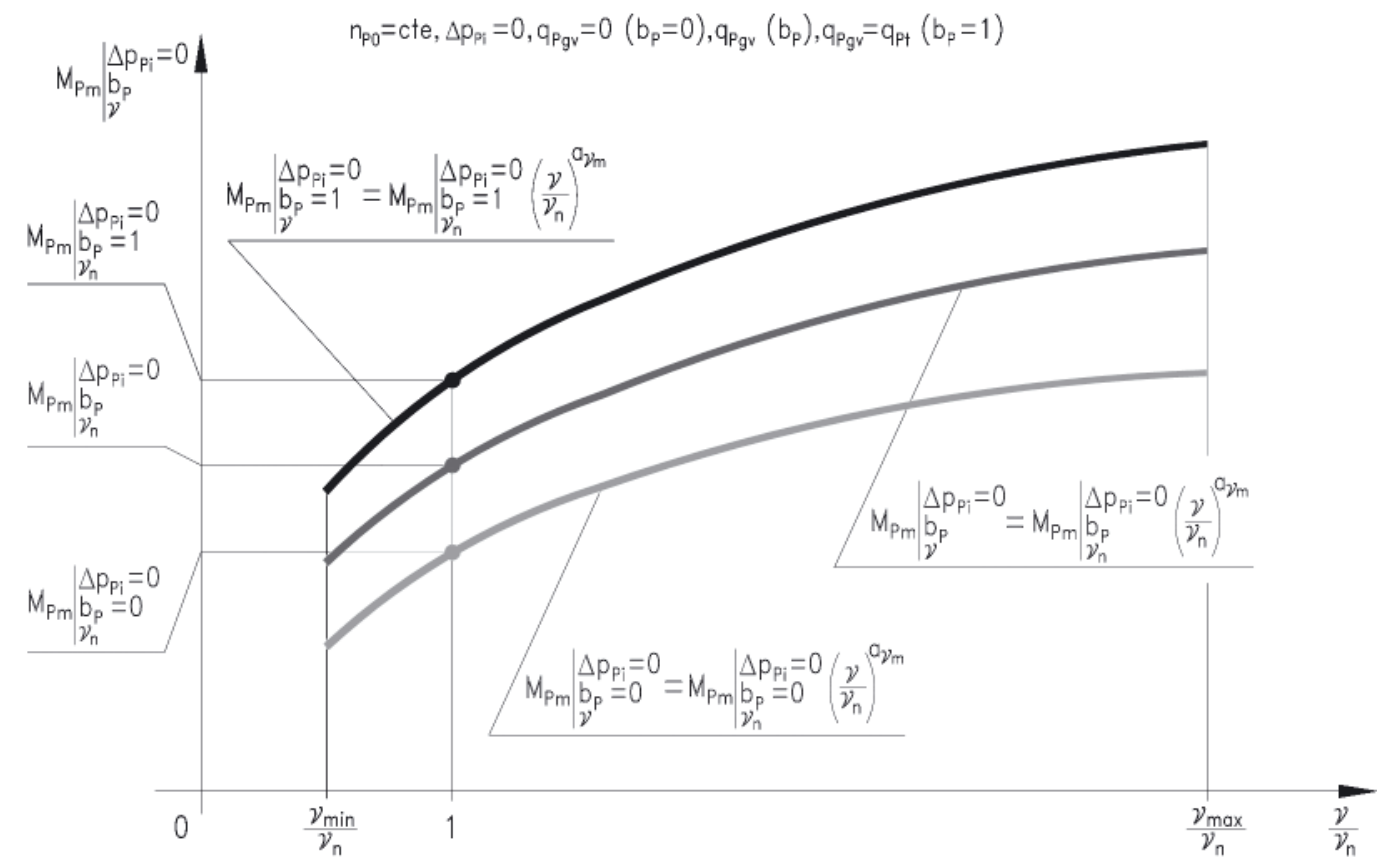

Fig. 6. Torque $M_{P m \mid \Delta p_{p i}=0, b_{p}, v}$ of mechanical losses in a piston (axial or radial) pump with crankcase filled with liquid and with variable capacity $q_{P v_{v}}=b_{P} q_{P t}$ per one shaft revolution, at the indicated increase $\Delta p_{P i}=0$ of pressure in the pump working chambers, as a function of the ratio of viscosity $v$ to reference viscosity $v_{n}-v / v_{n}$ - graphical interpretation of theoretical model (4); capacity $q_{P g v}$ per one shaft revolution (coefficient $b_{P}$ of pump capacity): $q_{P g v}=0\left(b_{P}=0\right), q_{P g v}\left(b_{P}\right)$, $q_{P g v}=q_{P t}\left(b_{P}=1\right)$. Torque $M_{P m \mid \Delta p_{p i}=0, b_{p}, v}$ of mechanical losses in the pump without crankcase filled with liquid is practically independent of the liquid viscosity $v$ and is determined at the liquid reference viscosity $v_{n}$

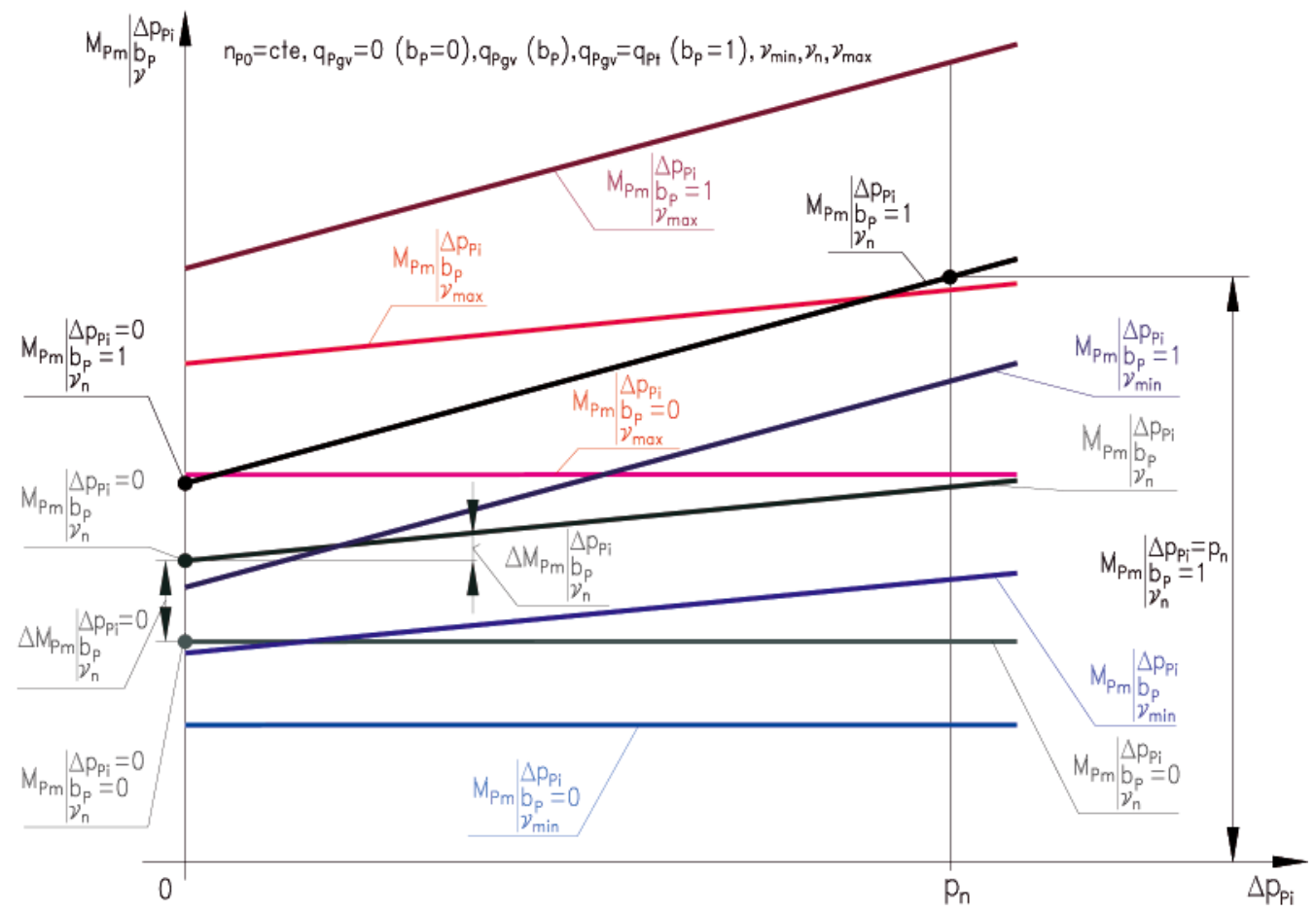

Fig. 7. Torque $M_{P m \mid \Delta p_{p}, b_{p}, v}$ of mechanical losses in a piston (axial or radial) pump with crankcase filled with liquid and with variable capacity $q_{P g v}=b_{P} q_{P t}$ per one shaft revolution, as a function of the indicated increase $\Delta p_{P i}$ of pressure in the pump working chambers - graphical interpretation of theoretical model (9); capacity $q_{P g v}$ per one shaft revolution (coefficient $b_{P}$ of pump capacity): $q_{P_{g v}}=0\left(b_{P}=0\right), q_{P g v}\left(b_{P}\right), q_{P g v}=q_{P t}\left(b_{P}=1\right)$; liquid viscosity $v_{\min }, v_{n}$ and $v_{\max }$. Torque $M_{P m \mid \Delta p_{p i}, b_{p}, v}$ of mechanical losses in the pump without the crankcase filled with liquid is practically independent of the liquid viscosity $v$ and is determined at the liquid reference viscosity $v_{n}$

The theoretical and mathematical models describe the torque $\mathrm{M}_{\mathrm{Pm}}$ of mechanical losses in the pump with theoretical (constant) capacity $\mathrm{q}_{\mathrm{Pt}}$ per one shaft revolution or with geometrical (variable) capacity $\mathrm{q}_{\mathrm{Pgv}}=\mathrm{b}_{\mathrm{P}} \mathrm{q}_{\mathrm{Pt}}$ per one shaft revolution:

- $\mathrm{q}_{\mathrm{Pt}}=\mathrm{q}_{\mathrm{P} \mid \Delta \mathrm{p}_{\mathrm{pi}}=0, \mathrm{p}_{\mathrm{pli}}=0, \mathrm{~b}_{\mathrm{p}}=1, \mathrm{v}_{\mathrm{n}}}$ is a theoretical capacity per one shaft revolution of the pump with constant capacity per one revolution $\left(\mathrm{b}_{\mathrm{P}}=1\right)$ determined at $\Delta \mathrm{p}_{\mathrm{Pi}}=0, \mathrm{p}_{\mathrm{Pli}}=0$ and $v_{\mathrm{n}}$, which is equal to the working volume of the working chambers created during one shaft revolution,

- $\mathrm{q}_{\mathrm{Pgv}}=\mathrm{b}_{\mathrm{P}} \mathrm{q}_{\mathrm{Pt}}$ is a geometrical capacity per one shaft revolution of the pump with variable capacity per one revolution at $\Delta \mathrm{p}_{\mathrm{Pi}}=0, \mathrm{p}_{\mathrm{Pli}}=0$ and $\mathrm{v}_{\mathrm{n}}$, which is equal to the working volume of the working chambers created during one shaft 
revolution. Capacity $\mathrm{q}_{\mathrm{Pgv}}$ per one shaft revolution changes in the $0 \leq \mathrm{q}_{\mathrm{PgV}} \leq \mathrm{q}_{\mathrm{Pt}}$ range and coefficient $\mathrm{b}_{\mathrm{P}}=\mathrm{q}_{\mathrm{PgV}} / \mathrm{q}_{\mathrm{Pt}}$ of the pump capacity changes in the $0 \leq b_{P} \leq 1$ range.

The proposed mathematical models describing the torque $M_{P m}$ of mechanical losses in the pump, related to theoretical models of the torque of mechanical losses, take the form:

- in a pump with theoretical (constant) capacity $\mathrm{q}_{\mathrm{pt}}$ per one shaft revolution $\left(b_{\mathrm{P}}=1\right)$ [referring to theoretical model (8)]:

$$
\begin{gathered}
\mathrm{M}_{\mathrm{Pm} \mid \Delta \mathrm{p}_{\mathrm{Pi}}, v}=\mathrm{k}_{4.1} \mathrm{M}_{\mathrm{Pt}}\left(\frac{v}{v_{\mathrm{n}}}\right)^{\mathrm{a}_{v \mathrm{~m}}}+\mathrm{k}_{4.2} \mathrm{M}_{\mathrm{Pt}} \frac{\Delta \mathrm{p}_{\mathrm{Pi}}}{\mathrm{p}_{\mathrm{n}}}= \\
=\left[\mathrm{k}_{4.1}\left(\frac{v}{v_{\mathrm{n}}}\right)^{\mathrm{a}_{\mathrm{vm}}}+\mathrm{k}_{4.2} \frac{\Delta \mathrm{p}_{\mathrm{Pi}}}{\mathrm{p}_{\mathrm{n}}}\right] \mathrm{M}_{\mathrm{Pt}}= \\
=\left[\mathrm{k}_{4.1}\left(\frac{v}{v_{\mathrm{n}}}\right)^{\mathrm{a}_{v \mathrm{~m}}}+\mathrm{k}_{4.2} \frac{\Delta \mathrm{p}_{\mathrm{Pi}}}{\mathrm{p}_{\mathrm{n}}}\right] \frac{\mathrm{q}_{\mathrm{Pt}} \mathrm{p}_{\mathrm{n}}}{2 \Pi}
\end{gathered}
$$

where:

$$
\mathrm{k}_{4.1}=\frac{\mathrm{M}_{\mathrm{Pm} \mid \Delta \mathrm{p}_{\mathrm{Pi}}=0, \mathrm{~b}_{\mathrm{P}}=1, v_{\mathrm{n}}}}{\mathrm{M}_{\mathrm{Pt}}}=\frac{\mathrm{M}_{\mathrm{Pm} \mid \Delta \mathrm{p}_{\mathrm{Pi}}=0, \mathrm{~b}_{\mathrm{P}}=1, v_{\mathrm{n}}}}{\frac{\mathrm{q}_{\mathrm{Pt}} \mathrm{p}_{\mathrm{n}}}{2 \Pi}}
$$

$$
\mathrm{k}_{4.2}=\frac{\Delta \mathrm{M}_{\mathrm{Pm} \mid \Delta \mathrm{p}_{\mathrm{Pi}}, \mathrm{b}_{\mathrm{P}}=1, v_{\mathrm{n}}}}{\mathrm{M}_{\mathrm{Pi}}}=\frac{\Delta \mathrm{M}_{\mathrm{Pm} \mid \Delta \mathrm{p}_{\mathrm{Pi}}, \mathrm{b}_{\mathrm{P}}=1, v_{\mathrm{n}}}}{\frac{\mathrm{q}_{\mathrm{Pt}} \Delta \mathrm{p}_{\mathrm{Pi}}}{2 \Pi}}=
$$$$
=\frac{\mathrm{M}_{\mathrm{Pm} \mid \Delta \mathrm{p}_{\mathrm{Pi}}, \mathrm{b}_{\mathrm{P}}=1, v_{\mathrm{n}}}-\mathrm{M}_{\mathrm{Pm} \mid \Delta \mathrm{p}_{\mathrm{Pi}}=0, \mathrm{~b}_{\mathrm{P}}=1, v_{\mathrm{n}}}}{\frac{\mathrm{q}_{\mathrm{Pt}} \Delta \mathrm{p}_{\mathrm{Pi}}}{2 \Pi}}=
$$$$
=\frac{\mathrm{M}_{\mathrm{Pm} \mid \Delta \mathrm{p}_{\mathrm{Pi}}=\mathrm{p}_{\mathrm{n}}, \mathrm{b}_{\mathrm{P}}=1, v_{\mathrm{n}}}-\mathrm{M}_{\mathrm{Pm} \mid \Delta \mathrm{p}_{\mathrm{Pi}}=0, \mathrm{~b}_{\mathrm{P}}=1, v_{\mathrm{n}}}}{\frac{\mathrm{q}_{\mathrm{Pt}} \mathrm{p}_{\mathrm{n}}}{2 \Pi}}=
$$

$$
=\frac{\mathrm{M}_{\mathrm{Pm} \mid \Delta \mathrm{p}_{\mathrm{Pi}}=\mathrm{p}_{\mathrm{n}}, \mathrm{b}_{\mathrm{P}}=1, v_{\mathrm{n}}}-\mathrm{M}_{\mathrm{Pm} \mid \Delta \mathrm{p}_{\mathrm{Pi}}=0, \mathrm{~b}_{\mathrm{P}}=1, v_{\mathrm{n}}}}{\mathrm{M}_{\mathrm{Pt}}}=
$$

- in a pump with geometrical (variable) capacity $\mathrm{q}_{\mathrm{Pgv}}$ $\left(\mathrm{q}_{\mathrm{Pgv}}=\mathrm{b}_{\mathrm{P}} \mathrm{q}_{\mathrm{Pt}}\right)$ per one shaft revolution [referring to theoretical models (9), (10) and (11)]:

$$
\mathrm{M}_{\mathrm{Pm} \mid \Delta \mathrm{p}_{\mathrm{Pi}}, \mathrm{b}_{\mathrm{P}}, v}=
$$

$=\left(\mathrm{k}_{4.1 .1}+\mathrm{k}_{4.1 .2} \mathrm{~b}_{\mathrm{P}}\right) \mathrm{M}_{\mathrm{Pt}}\left(\frac{v}{v_{\mathrm{n}}}\right)^{\mathrm{a}_{\mathrm{vm}}}+\mathrm{k}_{4.2} \mathrm{M}_{\mathrm{Pt}} \mathrm{b}_{\mathrm{P}} \frac{\Delta \mathrm{p}_{\mathrm{Pi}}}{\mathrm{p}_{\mathrm{n}}}=$

$=\left[\left(\mathrm{k}_{4.1 .1}+\mathrm{k}_{4.1 .2} \mathrm{~b}_{\mathrm{P}}\right)\left(\frac{\mathrm{v}}{v_{\mathrm{n}}}\right)^{\mathrm{a}_{\mathrm{vm}}}+\mathrm{k}_{4.2} \mathrm{~b}_{\mathrm{P}} \frac{\Delta \mathrm{p}_{\mathrm{Pi}}}{\mathrm{p}_{\mathrm{n}}}\right] \mathrm{M}_{\mathrm{Pt}}=$

$=\left[\left(\mathrm{k}_{4.1 .1}+\mathrm{k}_{4.1 .2} \mathrm{~b}_{\mathrm{P}}\right)\left(\frac{v}{v_{\mathrm{n}}}\right)^{\mathrm{a}_{v \mathrm{~m}}}+\mathrm{k}_{4.2} \mathrm{~b}_{\mathrm{P}} \frac{\Delta \mathrm{p}_{\mathrm{Pi}}}{\mathrm{p}_{\mathrm{n}}}\right] \frac{\mathrm{q}_{\mathrm{Pt}} \mathrm{p}_{\mathrm{n}}}{2 \Pi}$

where:

$\mathrm{k}_{4.1 .1}=\frac{\mathrm{M}_{\mathrm{Pm} \mid \Delta \mathrm{p}_{\mathrm{Pi}}=0, \mathrm{~b}_{\mathrm{P}}=0, v_{\mathrm{n}}}}{\mathrm{M}_{\mathrm{Pt}}}=\frac{\mathrm{M}_{\mathrm{Pm} \mid \Delta \mathrm{p}_{\mathrm{Pi}}=0, \mathrm{~b}_{\mathrm{P}}=0, v_{\mathrm{n}}}}{\frac{\mathrm{q}_{\mathrm{Pt}} \mathrm{p}_{\mathrm{n}}}{2 \Pi}}$

$$
\begin{aligned}
\mathrm{k}_{4.1 .2}= & \frac{\mathrm{M}_{\mathrm{Pm} \mid \Delta \mathrm{p}_{\mathrm{Pi}}=0, \mathrm{~b}_{\mathrm{P}}=1, v_{\mathrm{n}}}-\mathrm{M}_{\mathrm{Pm} \mid \Delta \mathrm{p}_{\mathrm{Pi}}=0, \mathrm{~b}_{\mathrm{P}}=0, v_{\mathrm{n}}}}{\mathrm{M}_{\mathrm{Pt}}} \\
= & \frac{\mathrm{M}_{\mathrm{Pm} \mid \Delta \mathrm{p}_{\mathrm{Pi}}=0, \mathrm{~b}_{\mathrm{P}}=1, v_{\mathrm{n}}}-\mathrm{M}_{\mathrm{Pm} \mid \Delta \mathrm{p}_{\mathrm{Pi}}=0, \mathrm{~b}_{\mathrm{P}}=0, v_{\mathrm{n}}}}{\frac{\mathrm{q}_{\mathrm{Pt}} \mathrm{p}_{\mathrm{n}}}{2 \Pi}}
\end{aligned}
$$

$$
\begin{gathered}
\mathrm{k}_{4.2}=\frac{\Delta \mathrm{M}_{\mathrm{Pm} \mid \Delta \mathrm{p}_{\mathrm{Pi}}, \mathrm{b}_{\mathrm{P}}, v_{\mathrm{n}}}}{\mathrm{M}_{\mathrm{Pi}}}= \\
=\frac{\Delta \mathrm{M}_{\mathrm{Pm} \mid \Delta \mathrm{p}_{\mathrm{Pi}}, \mathrm{b}_{\mathrm{P}}, v_{\mathrm{n}}}}{\frac{\mathrm{b}_{\mathrm{P}} \mathrm{q}_{\mathrm{Pt}} \Delta \mathrm{p}_{\mathrm{Pi}}}{2 \Pi}}=\frac{\Delta \mathrm{M}_{\mathrm{Pm} \mid \Delta \mathrm{p}_{\mathrm{Pi}}, \mathrm{b}_{\mathrm{P}}=1, v_{\mathrm{n}}}}{\frac{\mathrm{q}_{\mathrm{Pt}} \Delta \mathrm{p}_{\mathrm{Pi}}}{2 \Pi}}= \\
=\frac{\mathrm{M}_{\mathrm{Pm} \mid \Delta \mathrm{p}_{\mathrm{Pi}}=\mathrm{p}_{\mathrm{n}}, \mathrm{b}_{\mathrm{P}}=1, v_{\mathrm{n}}}-\mathrm{M}_{\mathrm{Pm} \mid \Delta \mathrm{p}_{\mathrm{Pi}}=0, \mathrm{~b}_{\mathrm{P}}=1, v_{\mathrm{n}}}}{\frac{\mathrm{q}_{\mathrm{Pt}} \mathrm{p}_{\mathrm{n}}}{2 \Pi}}= \\
=\frac{\mathrm{M}_{\mathrm{Pm} \mid \Delta \mathrm{p}_{\mathrm{Pi}}=\mathrm{p}_{\mathrm{n}}, \mathrm{b}_{\mathrm{P}}=1, v_{\mathrm{n}}}-\mathrm{M}_{\mathrm{Pm} \mid \Delta \mathrm{p}_{\mathrm{Pi}}=0, \mathrm{~b}_{\mathrm{P}}=1, v_{\mathrm{n}}}}{\mathrm{M}_{\mathrm{Pt}}}
\end{gathered}
$$

\section{Commentary:}

- The sum $\left(\mathrm{k}_{4.1 .1}+\mathrm{k}_{4.1 .2}\right)$ of coefficients used in mathematical model (15) describing the torque $\mathrm{M}_{\mathrm{Pm}}$ of mechanical losses in the pump with geometrical (variable) capacity $\mathrm{q}_{\mathrm{Pgv}}\left(\mathrm{q}_{\mathrm{Pgv}}=\mathrm{b}_{\mathrm{P}} \mathrm{q}_{\mathrm{Pt}}\right)$ per one shaft revolution is equal to coefficient $\mathrm{k}_{4.1}$ used in the mathematical model (12) describing the torque $\mathrm{M}_{\mathrm{Pm}}$ of mechanical losses in that pump working as a pump with theoretical (constant) capacity per one shaft revolution:

$\mathrm{k}_{4.1 .1}+\mathrm{k}_{4.1 .2}=\mathrm{k}_{4.1}$.

- Coefficient $\mathrm{k}_{4.2}$ used in mathematical model (15) describing the torque $\mathrm{M}_{\mathrm{Pm}}$ of mechanical losses in the pump with geometrical (variable) capacity $\mathrm{q}_{\mathrm{Pgv}}\left(\mathrm{q}_{\mathrm{Pgv}}=\mathrm{b}_{\mathrm{P}} \mathrm{q}_{\mathrm{Pt}}\right)$ per one shaft revolution is equal to coefficient $\mathrm{k}_{4.2}$ used in the mathematical model (12) describing the torque $\mathrm{M}_{\mathrm{Pm}}$ of mechanical losses in that pump working as a pump with theoretical (constant) capacity $\mathrm{q}_{\mathrm{Pt}}$ per one shaft revolution.

\section{CONCLUSIONS}

1. The theoretical and mathematical models have been developed of the torque $\mathrm{M}_{\mathrm{Pm}}$ of mechanical losses in the „working chambers - shaft" assembly of a displacement pump with constant $\mathrm{q}_{\mathrm{Pt}}\left(\mathrm{V}_{\mathrm{Pt}}\right)$ and variable $\mathrm{q}_{\mathrm{Pgv}}=\mathrm{b}_{\mathrm{P}} \mathrm{q}_{\mathrm{Pt}}\left(\mathrm{V}_{\mathrm{Pgv}}\right)$ capacity per one shaft revolution.

The models describe the relation of the torque $\mathrm{M}_{\mathrm{Pm}}$ of mechanical losses in the assembly to the torque:

$$
\mathrm{M}_{\mathrm{Pi}}=\frac{\mathrm{q}_{\mathrm{Pgv}} \Delta \mathrm{p}_{\mathrm{Pi}}}{2 \Pi}=\frac{\mathrm{b}_{\mathrm{P}} \mathrm{q}_{\mathrm{Pt}} \Delta \mathrm{p}_{\mathrm{Pi}}}{2 \Pi}
$$

indicated in the pump working chambers and also to the working liquid viscosity $v$ at the pump inlet, changing in the $v_{\min } \leq v \leq v_{\max }$ range. It is assumed that a small change of the pump driving motor rotational speed $\mathrm{n}_{\mathrm{P}}$ (due to the changing pump shaft torque $\mathrm{M}_{\mathrm{P}}$ loading the motor) practically does not influence the torque $\mathrm{M}_{\mathrm{Pm}}$ of losses.

The indicated torque $\mathrm{M}_{\mathrm{Pi}}$ in the pump working chambers and the working liquid viscosity $v$ are parameters independent of the torque $\mathrm{M}_{\mathrm{Pm}}$ of mechanical losses in the „working chambers - shaft" assembly. 
The models describe also the relation of torque $\mathrm{M}_{\mathrm{Pm}}$ to the capacity $\mathrm{q}_{\mathrm{Pgv}}$ per one shaft revolution (coefficient $\mathrm{b}_{\mathrm{P}}=\mathrm{q}_{\mathrm{Pgv}} / \mathrm{q}_{\mathrm{Pt}}$ of the pump capacity) in a pump with variable capacity per onerevolution.

The assumedchange of $\mathrm{q}_{\mathrm{Pgv}}\left(\mathrm{b}_{\mathrm{P}}\right)$ is in the $0 \leq \mathrm{q}_{\mathrm{pgv}} \leq \mathrm{q}_{\mathrm{Mt}}$ $\left(0 \leq b_{p} \leq 1\right)$ range.

2. The mathematical models of the torque $\mathrm{M}_{\mathrm{Pm}}$ of mechanical losses are based on defined coefficients $\mathrm{k}_{\mathrm{i}}$ of energy losses relating the torque of mechanical losses to a reference value, i.e. to:

- theoretical torque $\mathrm{M}_{\mathrm{Pt}}$ of a pump with theoretical (constant) capacity $\mathrm{q}_{\mathrm{pt}}$ per one shaft revolution, determined at the increase $\Delta \mathrm{p}_{\mathrm{Pi}}$ of pressure in the pump equal to the nominal pressure $\mathrm{p}_{\mathrm{n}}$ of system operation $\left(\Delta \mathrm{p}_{\mathrm{Pi}}=\mathrm{p}_{\mathrm{n}}\right)$, with:

- known values of the pump capacity coefficient $\mathrm{b}_{\mathrm{P}}=\mathrm{q}_{\mathrm{Pgv}} / \mathrm{q}_{\mathrm{Pt}}$,

- assumption of practically constant pump speed $n_{P}$ equal to the speed $\mathrm{n}_{\mathrm{P} 0}$ of the unloaded pump shaft $\left(\mathrm{n}_{\mathrm{P}}=\mathrm{n}_{\mathrm{P} 0}\right)$.

3. The mathematical models of the torque $\mathrm{M}_{\mathrm{Pm}}$ of mechanical losses in the ,working chambers - shaft" assembly should correspond with the models of volumetric losses in the working chambers and with the models of pressure losses in the pump channels.

\section{BIBLIOGRAPHY}

1. Paszota Z.: Graphical presentation of the power of energy losses and power developed in the elements of hydrostatic drive and control system. Part I - Rotational hydraulic motor speed series throttling control systems. Chapter in the monograph: ,,Research, design, production and operation of hydraulic systems" (in Polish), Adam Klich, Edward Palczak and Andrzej Meder editors. „Cylinder” Library. Komag Mining Mechanisation Centre, Gliwice 2008

2. Paszota Z.: Graphical presentation of the power of energy losses and power developed in the elements of hydrostatic drive and control system. Part II - Rotational hydraulic motor speed parallel throttling control and volumetric control systems. Chapter in the monograph: ,,Research, design, production and operation of hydraulic systems" (in Polish), Adam Klich, Edward Palczak and Andrzej Meder editors. „Cylinder” Library. Komag Mining Mechanisation Centre, Gliwice 2008

3. Paszota Z.: Direction of increase of power stream in the hydrostatic drive and control system. Graphical presentation of the power of energy losses and power developed in the elements of hydrostatic drive and control system. Part I - Rotational hydraulic motor speed series throttling control systems (in Polish), Napędy i sterowanie, scientific monthly, No 10 (114), October 2008

4. Paszota Z.: Direction of increase of power stream in the hydrostatic drive and control system. Graphical presentation of the power of energy losses and power developed in the elements of hydrostatic drive and control system. Part II - Rotational hydraulic motor speed parallel throttling control and volumetric control systems (in Polish), Napędy i sterowanie, scientific monthly, No 11 (115), November 2008

5. Paszota Z.: Graphical presentation of the power of energy losses and power developed in the elements of hydrostatic drive and control system. Part I - Rotational hydraulic motor speed series throttling control systems. Polish Maritime Research 3 (57) 2008, Vol. 15

6. Paszota Z.: Graphical presentation of the power of energy losses and power developed in the elements of hydrostatic drive and control system. Part II - Rotational hydraulic motor speed parallel throttling control and volumetric control systems. Polish Maritime Research 4 (58) 2008,Vol. 15

7. Paszota Z.: The operating field of a hydrostatic drive system. Chapter in the monograph: ,Research, design, production and operation of hydraulic systems" (in Polish), Adam Klich, Antoni Kozieł and Edward Palczak editors. „Cylinder” Library. Komag Mining Mechanisation Centre, Gliwice 2009

8. Paszota Z.: Parameters of the energy efficiency investigations of pumps and hydraulic motors. The operating field of a hydrostatic drive system (in Polish), Napędy i sterowanie, scientific monthly, No 11 (127), November 2009

9. Paszota Z.: The operating field of a hydrostatic drive system parameters of the energy efficiency investigations of pumps and hydraulic motors. Polish Maritime Research 4 (62) 2009, Vol. 16

10.Paszota Z.: Energy losses in a rotational hydraulic motordefinitions and relations for evaluation of the efficiency of motor and hydrostatic drive. Chapter in the monograph: ,, Research, design, production and operation of hydraulic systems" (in Polish), Adam Klich, Antoni Kozieł and Edward Palczak editors. „Cylinder" Library. Komag Mining Mechanisation Centre, Gliwice 2010

11.Paszota Z:: Theoretical and mathematical models of the torque of mechanical losses in a hydraulic rotational motor for hydrostatic drive. Chapter in the monograph: „, Research, design, production and operation of hydraulic systems" (in Polish), Adam Klich, Antoni Kozieł and Edward Palczak editors. „Cylinder” Library. Komag Mining Mechanisation Centre, Gliwice 2010

12.Paszota Z.: Energy losses in a rotational hydraulic motor definitions and relations for evaluation of the efficiency of motor and hydrostatic drive (in Polish), Napędy i sterowanie, scientific monthly, No 10 (138), October 2010

13.Paszota Z.: Theoretical and mathematical models of the torque of mechanical losses in a hydraulic rotational motor for hydrostatic drive (in Polish), Napędy i sterowanie, scientific monthly, No 11(139), November 2010

14.Paszota Z.: Energy losses in the hydraulic rotational motor - definitions and relations for evaluation of the efficiency of motor and hydrostatic drive. Polish Maritime Research 2 (65) 2010, Vol. 17

15.Paszota Z.: Theoretical and mathematical models of the torque of mechanical losses in a hydraulic rotational motor for hydrostatic drive. Polish Maritime Research 3 (66) 2010,Vol. 17

16.Paszota Z.: Hydrostatic drives as safe and energy saving machines (in Polish), Napędy i sterowanie, scientific monthly, No 1(141), January 2011

17.Paszota Z.: Hydrostatic drives as safe and energy saving machines (in Polish), Proceedings of the „Innovative machines and Technologies - Safety" conference, Szczyrk 03 - 04 February 2011

18.Paszota Z.: Hydrostatic drives as safe and energy saving machines. The drive investigation method compatible with the diagram of power increase opposite to the direction of power flow. Polish Maritime Research 1(68) 2011,Vol. 18

\section{CONTACT WITH THE AUTHOR}

Prof. Zygmunt Paszota

Faculty of Ocean Engineering and Ship Technology

Gdansk University of Technology Narutowicza 11/12 80-233 Gdansk, POLAND e-mail: zpaszota@pg.gda.pl 